
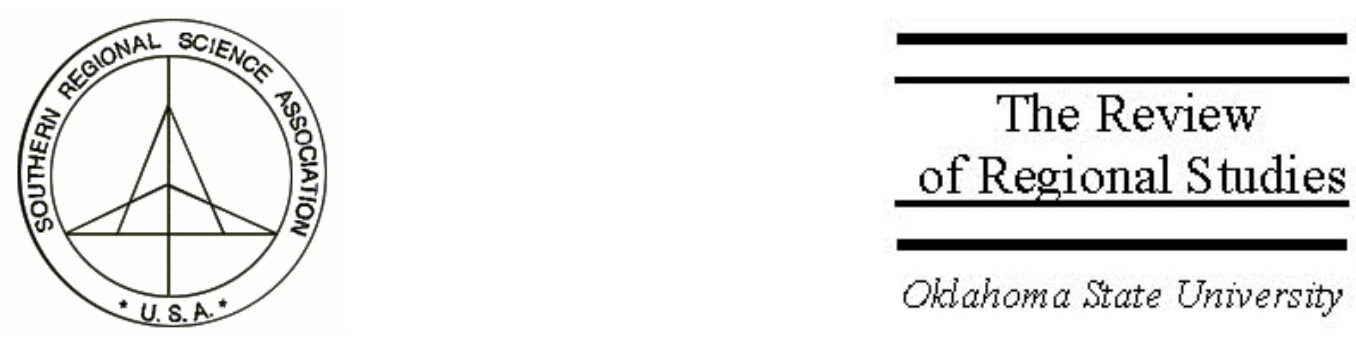

\title{
Amenities and Non-Farm Employment Growth in the U.S. Midwest: The Impact of Recreational Amenities in Neighboring Counties
}

\author{
Daniel C. Monchuk \\ Department of Economics, 118 College Drive \#5072, University of Southern Mississippi, \\ Hattiesburg, MS 39402, email: dmonchuk@gmail.com
}

\section{John A. Miranowski}

Department of Economics, 260 Heady Hall, Iowa State University, Ames, IA 50011, email: jmirski@iastate.edu

\begin{abstract}
This study examines the role of recreational amenities, both within the county as well in neighboring counties, on employment growth using data from 618 counties in the U.S. midwest. Using a wide range of amenity variables and spatial econometric methods, we find that natural and recreational amenities have played a role in non-farm employment growth over the years 1969 to 2000 . Further, the results also indicate that the presence of recreational amenities in neighboring counties have also played an important role in explaining employment growth as opposed to only amenities within the county itself.
\end{abstract}

Keywords: Recreational amenities; Spatial econometrics; Employment growth

JEL classification: Q26; R11; R12

We would like to thank the editor and two anonymous reviewers for their comments and suggestions. The usual caveats apply. 


\section{INTRODUCTION}

In general it is believed that, ceteris paribus, people and business are more likely to locate where there are more amenities than where there are fewer. In the last century this move has been quite obvious as employers and people alike have continued to move west to the mountains of Colorado or onward to the West Coast where scenic and recreational amenities abound. These amenities clearly have value, as any student renting a studio in Berkeley can tell you. The same is true for the ski instructor in Aspen who will work for minimum wage just to partake of the beautiful scenery and purchase a discounted ski pass. A number of studies have demonstrated that positive amenities may be capitalized into wages and higher housing values (Roback 1982, 1988; Voith 1991). While capitalization of the amenity benefits into higher housing values and lower wages may occur, there is a growing literature that suggests amenities may be developed for economic policy purposes. Research by Gottlieb (1995) suggests that amenities have potential as an economic growth tool since they affect the location decisions of both firms and workers. The fact that income levels alone are an imperfect indicator of welfare is one reason quality of life measures are being considered when analyzing neoclassical economic issues such as convergence (Marchante and Ortega 2006; Royuela and Artís 2006). Further work by Dissart and Deller (2000), Halstead and Deller (1997), and Rudzitis (1999) has shown that quality of life plays an important role in economic growth at the community level. Using a relatively large set of recreational and natural amenity indicators, Deller et al. (2001) provide evidence that changes in the levels of population, employment, and income generally respond positively to a broad group of amenities.

While America is becoming increasingly urban, opportunities for recreational amenities, especially those of the camping and outdoor persuasion, are generally limited within welldeveloped urban centers. This does not imply, however, that such areas cannot and do not benefit from outdoor recreation opportunities. A common weekend activity for families and individuals alike is to escape the city and head out to a lake, park, or campground for the weekend. Incidentally, these are often located in rural areas where urban congestion is limited. In the Midwest, 30 minutes to an hour of driving is typically more than adequate to transport a family away from home, across county lines, and into an area with attractive camping, swimming, and hiking opportunities. So, in effect, it is the recreational amenities in spatial proximity that are contributing to economic activity in the home county rather than just amenities within the home county itself. While few studies, if any, have examined the role of surrounding amenities on county economic activity, a few papers have explicitly considered the regional effects as well as local effects of economic activity. In a study on population growth by Khan, Orazem, and Otto (2001), the authors found wage growth in geographically near counties complemented population growth in the home county. Other studies considering regional as opposed to local effects include Blomquist, Berger, and Hoehn, (1988) and Gottlieb (1995). Clearly any rural policy aimed at exploiting outdoor recreational amenities needs to consider spatial proximity effects as well local effects. Many previous studies, especially at the county level, have ignored this spatial relationship and have incorrectly made the classical statistical assumption of independence between counties when conducting statistical analyses. Since individuals and families are not confined to their 
county of residence, it is not reasonable to only consider the outdoor recreational amenities in the home county and ideally should include surrounding counties as well. One can easily envision a county that is rich in employment growth and local development opportunity but may lack of outdoor amenities within the county itself. Therefore, to look at the total impact of amenities, especially those outdoor amenities that are land- and water-intensive recreation, we hypothesize that recreational amenities in surrounding counties have a significant impact on home county employment growth.

In this paper we are primarily interested in the economic growth impacts, i.e., non-farm employment growth, of outdoor recreational and natural amenities. While a number of studies examine and model rural economic growth with respect to amenities such as those described above, these models generally do not consider the following: 1) the growth effects of outdoor recreation amenities in neighboring counties, 2) unobservable spatial autocorrelation, and 3) the impact of locally originating new technology and knowledge originating in local and proximate areas. The inclusion of neighboring amenities when examining economic growth is well grounded since economic agents within a county, unlike countries and to a lesser degree states, are restricted in movement across county lines only by their opportunity cost of traveling a relatively short distance to an adjacent county. Further, other spatial considerations such as unobservable inter-county relationships and other proximity effects motivate spatial econometric estimation methods. Finally, failure to include technology impacts, the fundamental building block of economic growth theory, may lead to missing variable bias in any growth model, especially when evaluated over long periods of time. While traditional models of county-level growth have generally not included a measure of new technology, it is clear innovation occurs locally and the extent to which benefits are also local, as opposed to national, deserve further consideration.

In the next section, we draw from the economic literature on both amenities and various theories of modern economic growth to develop a conceptual model of employment growth that is elaborated on in the subsequent section where the empirical model is developed and the variables, methods, and data are presented. In the fourth section the results are presented where county data from the midwest states of Minnesota, Iowa, Missouri, Kansas, Nebraska, South Dakota, and North Dakota are used to estimate the spatial effects of a variety of amenities and other key variables on total non-farm employment growth. Finally, the last section summarizes the policy implications for rural development based on the findings.

\section{CONCEPTUAL FRAMEWORK}

Modern economic growth literature is shifting emphasis from the traditional neoclassical framework to endogenous growth factors. Modern growth theories focus on the roles of ideas and technology embodied in human capital (Lucas 1988), physical capital (Romer 1986), natural capital (Castle 1988), and initial conditions including infrastructure. Glaeser et al. (1992) and Glaeser, Scheinkman, and Schleifer (1995) have added cross-industry externalities and derived empirical estimates of total and sector employment growth in key industries for U.S. cities. Obviously, economic growth is far more complex than that captured by these stylized macro models, but these models provide a useful starting point. 
The underlying theoretical model for this analysis follows Glaeser et al. (1992), which described employment growth in city-industries in the U.S. Firms are assumed to take output (the numeraire) prices, wages, $w_{t}$, and technology, $A_{t}$, as given and maximize a single input objective function

$$
A_{t} f\left(l_{t}\right)-w_{t} l_{t} .
$$

The firms choose labor input, $l_{t}$, such that the marginal product of labor is equal to the wage rate and the first order condition for an interior solution is $A_{t} f^{\prime}\left(l_{t}\right)-w_{t}=0$. Taking this derivative again with respect to labor in $t+1$ we can write the ratio of these two derivatives at two points in time:

$$
\frac{A_{t+1}}{A_{t}} \frac{f^{\prime}\left(l_{t+1}\right)}{f^{\prime}\left(l_{t}\right)}-\frac{w_{t+1}}{w_{t}}=0 .
$$

Assuming a Cobb-Douglas functional form for the production technology of $f(l)=l^{a}$, we can substitute into (2) and take logs to get labor growth described by the following relationship

$$
\begin{aligned}
& \ln \left(\frac{l_{t+1}}{l_{t}}\right)=\beta_{1} \ln \left(\frac{w_{t+1}}{w_{t}}\right)+\widetilde{\beta}_{2} \ln \left(\frac{A_{t+1}}{A_{t}}\right) \\
& \text { where } \beta_{1}=\frac{1}{\alpha-1} \text { and } \beta_{2}=\frac{1}{1-\alpha} .
\end{aligned}
$$

Glaeser et al. (1992) divide growth in technology into two parts-local (city) and national. We also divide technology into two components-local (county) and midwest regional. We describe this relationship using a Cobb-Douglas functional form, $A=R^{\delta} A_{c}^{\gamma}$ where $R$ is regional technology and $A_{c}$ is local technology. The parameters $\delta$ and $\gamma$ represent the relative importance of such technology. Thus, we can express the growth in employment as a function of the growth in wages, regional technology growth and local technology growth, or

$$
\begin{aligned}
& \ln \left(\frac{l_{t+1}}{l_{t}}\right)=\beta_{1} \ln \left(\frac{w_{t+1}}{w_{t}}\right)+\widetilde{\beta}_{2} \ln \left(\frac{R_{t+1}}{R_{t}}\right)+\widetilde{\beta}_{3} \ln \left(\frac{A_{c, t+1}}{A_{c, t}}\right) \\
& \text { where } \widetilde{\beta}_{2}=\frac{\delta}{1-\alpha} \text { and } \widetilde{\beta}_{3}=\frac{\gamma}{1-\alpha} .
\end{aligned}
$$

To generalize the model in (4) further by incorporating worker choice of location, we can draw loosely on the work of Roback (1982) and Voith (1991) for the relationship between worker location and amenities. Ceteris paribus, a worker will be willing to locate in a region with a lower (higher) wage if the level of amenities is higher (lower). If $w$ is the 
implicit wage workers enjoy and take into consideration location characteristics, then $w$ is a function of both actual wages paid, $w_{a}$, and amenities, $s$. If we assume utility is increasing in amenities, then wages will be smaller in areas with higher amenities. If we assume this implicit wage function is $w=s^{\sigma} w_{a}^{\tau}$, where $\sigma<0$, and $\tau>0$, then equation (4) can be rewritten to include both amenities and actual wage paid by firms:

$$
\ln \left(\frac{l_{t+1}}{l_{t}}\right)=\widetilde{\beta}_{1} \ln \left(\frac{w_{a, t+1}}{w_{a, t}}\right)+\widetilde{\beta}_{2} \ln \left(\frac{R_{t+1}}{R_{t}}\right)+\widetilde{\beta}_{3} \ln \left(\frac{A_{c, t+1}}{A_{c, t}}\right)+\widetilde{\beta}_{4} \ln \left(\frac{s_{t+1}}{s_{t}}\right)
$$

where $\widetilde{\beta}_{1}=\frac{\tau}{\alpha-1}$ and $\widetilde{\beta}_{4}=\frac{\sigma}{\alpha-1}$.

These amenities yield utility to employees choosing to live in rural areas that may substitute for higher wages in metro areas. Sometimes these factors are referred to as natural capital or landscape when attempting to explain economic growth. In the section to follow, we discuss the treatment of each of the components on the right-hand side of equation (5).

\section{ECONOMETRIC MODEL AND DATA DESCRIPTION}

This section further develops the conceptual model outlined in the previous section by considering the different relationships on the right-hand side of equation (5). Here we also describe the different recreational amenities of interest and the data used to measure along with estimation strategy used to formulate and empirically estimate those employment growth correlates. We consider county growth in non-farm employment over the years 19692000 in addition to earlier and later sub-period growth for 1969-1984 and 1985-2000. Our sample includes 618 counties in the U.S. midwestern states of Minnesota, Iowa, Missouri, Kansas, Nebraska, South Dakota, and North Dakota. This particular grouping of states comprises the West North Central Division as established by the Census Bureau and represents a unique area in terms of its midwestern geography and the composition of the rural economy being heavily influenced by structural changes within the agricultural sector. During the larger growth period (point logarithmic), non-farm employment growth was 47 percent and within this interval averaged 23 and 24 percent for the 1969-1984 and 19852000 , respectively (Table 1). As stated earlier, this region is largely rural. In 1969 just over 92 percent of these counties had a population less than 50,000 and was largely unchanged by 2000 when the comparable statistic was slightly less than 90 percent. The farm sector is struggling with low prices, the number of farms is decreasing, and farm size is increasing (i.e., roughly 20 percent of the farms account for 80 percent of sales), the age distribution of farmers is shifting to the right (i.e., less than 2 percent of farmers were under 35 and, 34 percent were 65 and older in 2002), and over half of the farm operators work off-farm. Relative earnings in the region, especially in rural counties, are below the national average; but many rural people perceive this as a "quality-of-life" tradeoff. 


\section{TABLE 1}

Summary Statistics

\begin{tabular}{|c|c|c|c|c|c|c|}
\hline$\underline{\underline{\text { Variable }}}$ & Mean & Std. Dev. & Median & Minimum & Maximum & Count $^{+}$ \\
\hline \multicolumn{7}{|l|}{ Non-Farm Employment Gr. } \\
\hline $1969-2000$ & 0.469 & 0.366 & 0.413 & -0.504 & 2.074 & \\
\hline $1969-1985$ & 0.229 & 0.226 & 0.208 & -0.592 & 1.538 & \\
\hline $1985-2000$ & 0.238 & 0.200 & 0.223 & -0.389 & 1.212 & \\
\hline Amenity Scale & -1.661 & 1.495 & -1.705 & -6.400 & 2.99 & \\
\hline Rails to Trails (miles) & 16.5 & 73.7 & 0 & 0 & 1299 & 113 \\
\hline NRI Recreational Land (acres) & 1,665 & 5,104 & 0 & 0 & 54,000 & 212 \\
\hline NRI Recreational Water (acres) & 10,262 & 33,468 & 2300 & 0 & 461,400 & 527 \\
\hline Total Patents Filed 1975-2000 & 125 & 666 & 14 & 0 & 12,065 & \\
\hline Total Patents Filed 1975-1984 & 37 & 187 & 5 & 0 & 3,206 & \\
\hline Total Patents Filed 1985-2000 & 89 & 483 & 9 & 0 & 8,859 & \\
\hline $\begin{array}{l}\text { Total Non-Farm Employment } \\
1969\end{array}$ & 10,876 & 40,286 & 3,431 & 105 & 544,944 & \\
\hline $\begin{array}{l}\text { Total Non-Farm Employment } \\
1985\end{array}$ & 14,521 & 52,511 & 4,362 & 86 & 794,689 & \\
\hline Non-Farm Wage 1969 & 5.112 & 0.786 & 5.011 & 3.505 & 8.552 & \\
\hline Non-Farm Wage 1985 & 14.518 & 2.490 & 14.112 & 8.818 & 26.350 & \\
\hline Distance to a MSA & 109 & 68 & 97 & 0.5 & 359 & \\
\hline Interstate & & & & & & 176 \\
\hline \multicolumn{7}{|l|}{$\underline{\text { Patent Instruments }}$} \\
\hline Percent College Degree 1969 & 6.562 & 3.343 & 5.890 & 0.463 & 30.024 & \\
\hline Percent College Degree 1985 & 7.484 & 2.448 & 7.154 & 2.463 & 23.038 & \\
\hline Population 1969 & 26,217 & 73,742 & 11,657 & 624 & 967,826 & \\
\hline Population 1985 & 28,158 & 75,791 & 11,919 & 478 & 985,599 & \\
\hline Per capita income 1969 & 3.116 & 0.553 & 3.088 & 1.468 & 5.340 & \\
\hline Per capita income 1985 & 12.155 & 2.204 & 12.197 & 4.386 & 23.995 & \\
\hline \multicolumn{7}{|l|}{ State Counts } \\
\hline Iowa & & & & & & 99 \\
\hline Kansas & & & & & & 105 \\
\hline Minnesota & & & & & & 87 \\
\hline Missouri & & & & & & 115 \\
\hline Nebraska & & & & & & 93 \\
\hline North Dakota & & & & & & 53 \\
\hline South Dakota & & & & & & 66 \\
\hline
\end{tabular}


The change in value of natural amenities over time is believed to be a function of natural amenity and outdoor recreational opportunities endowments. In an attempt to capture the importance of natural capital in the growth process (e.g., Castle 1998), we use the potential flow of natural amenities and a variety of recreational amenities as a proxy. This relationship is described by

$$
\ln \left(\frac{S_{t+1, i}}{S_{t, i}}\right)=q\left(\text { nam }_{i}, r_{1, i}, r_{2, i}, r_{3, i}, \ldots, r_{R, i}\right)
$$

where $\operatorname{nam}_{i}$ is the natural amenity scale and $r_{a, i} a=1,2, \ldots, R$ are those recreational amenities available in county $i$. In general, we expect that the marginal effects of each of those variables in $q()$ to be positive so the marginal effect on employment is also positive. That is, an increased amenity level results in increased amenity value and, since $\widetilde{\beta}_{4}>0$, higher employment growth. As suggested by a reviewer, this might occur if amenities are a normal good and wages do not instantaneously adjust as the value of amenities rises with income. However, this positive relationship between amenities and employment need not always hold. In situations where the amenity is contained within the county in very close proximity to a center of economic growth, the proposed relationship may not only be insignificant but possibly negative. This could occur if the amenity is dated and no longer providing a flow of recreational services even though at an earlier stage may have been contributing to local prosperity. Another possible explanation follows from Gottlieb (1995), where the location of employment activity itself is in conflict with a particular amenity (i.e., a park adjacent to a factory or livestock operation). In the latter, close proximity of the amenity and location of employment are at odds whereas if there were more distance, there may be complementarities. In Blomquist, Berger, and Hoehn (1988), the authors refer to such incompatibility as production disamenities ${ }^{1}$ since the presence of a particular amenity can conceivably increase costs of production. It is possible that considerations such as these are one reason Lewis, Hunt, and Plantinga (2002; 2003) do not find any type of meaningful relationship between employment growth and public conservation lands in a study of midnorthern and north-eastern counties.

The variable $\operatorname{nam}_{i}$ is used to control for local climatic and topographic conditions. As a proxy for the flow of natural amenity services in the county, we use an index of natural amenities incorporating climatic factors, the type of land topography, and percent of the county covered with water. The natural amenity scale was constructed by the Economic Research Service (ERS) of USDA (McGranahan 1999). It is reasonable to postulate that rural counties should have a comparative advantage in the provision of these types of spaceintensive amenities (land and water based) compared to other types of amenities like convention centers and theme parks. Thus, in this paper we focus primarily on outdoor

${ }^{1}$ Production dissamenities may be one explanation for the findings of Henderson and McDaniel (2005) showing that retail and service employment is positively correlated with natural amenities while manufacturing employment is not. 
recreational amenities. To compute indicators of recreational amenities, we draw from the National Outdoor Recreation Supply Information System (NORSIS) dataset (Betz and Cordell 1998). The strategies for constructing our different indicators for recreational amenities depend upon the makeup of the data. If the data can be easily combined and interpreted, a simple sum is sufficient. However, if the recreational amenities in question are comprised of a number of different variables that are not of a comparable scale of measure, then we use principal component analysis to derive county indicators for each amenity. The recreational amenity indicators we have selected for this paper are: 1) rails to trails miles, 2) National Resources Inventory (NRI) land available for recreation, 3) NRI water areas for recreational uses, 4) National Park Service (NPS) amenities, 5) State Park Service amenities, 6) private campground amenities, 7) Forest Service amenities, and 8) amenities created by the U.S. Army Corps of Engineers. Each of these is described in greater detail below.

The first three indicators, 1-3, are constructed as simple sums within the county. The rails-to-trails amenity variable is the sum of rail beds converted to recreational trails for horseback, road biking, mountain biking, fishing access, skating, snowmobiling, and crosscountry skiing. NRI land available for recreation is the sum of acres available for municipal, county, state, Indian, and private recreational use. NRI land for water recreation is the sum of primary and secondary use recreation-based water acres. The average number of rails to trails miles was 16.5, and NRI recreational land and water acres were 1,665 and 10,262, respectively (Table 1). As can be seen from Table 1, each of these indicators varied considerably within the sample. ${ }^{2}$ The next set of recreational amenities, items $4-8$, are created using factor analysis ${ }^{3}$ in a method similar to Deller et al. (2001). Our recreational variable for State Park combined parks with camping, boating, fishing, hiking, primitive camping, picnicking, snowmobiling, and swimming. The new variable created was able to explain over 71 percent of the cumulative variation in state parks. The national park service amenity variable included information on the number of NPS units with biking trails, fishing, horse back riding trails, hiking, swimming, and cross country skiing and was able to explain 49 percent of the cumulative variation in NPS amenities. The recreational variable for private campground amenities is created using both private campgrounds and campground sites. The USDA forestry service amenity indicator is a combination of the numbers of boat ramps, picnic tables, developed swimming areas, trailheads, campgrounds, trailer sites, the number of miles open to the public, and total campground acres. This indicator explains almost 68 percent of the variation in forestry amenities. The final recreational amenity is based on the U.S. Army Corps of Engineers amenities and is comprised of total land and water recreational acres; total intensive use recreational acres; the numbers of individual campsites; individual picnic sites; boat ramps; designated swimming areas; trails; swimming pools; boat rentals; fishing docks; and miles of hiking, interpretive, bicycle, equestrian, off-road, and other trails. This indicator explains 78 percent of the cumulative variation.

\footnotetext{
${ }^{2}$ When estimating the growth equation, we transform these variables using natural logs. To facilitate the logarithmic transformation we follow common practice whereby we add one prior to taking logs. ${ }^{3}$ While we did try varying methods to compute aggregate variables such as the iterated principal factor (ipf), the method chosen did not appear to have significant impacts on our estimates.
} 
Using this recreational amenity data, we create an index based on all, 50 in total, of the individual indicators used to create our various different indices 1-8. This index was created using factor analysis and explains 53 percent of the variation in recreational amenities index. The index was created by summing variables created from loading on the first four eigenvalues. A map showing the dispersion of this recreational amenity parameter is given in Figure 1. The amenity index exhibits a spatial relationship and is generally higher in the northern and western regions of Minnesota and southern counties of Missouri, while lower in Nebraska and the western regions of Kansas.

As an alternative specification to equation (6), the amenity benefit in the home county is linked with recreational amenities in surrounding counties. We define a recreational neighborhood for county $i, J_{\mathrm{i}}$, as those counties within "close" proximity to the home county.
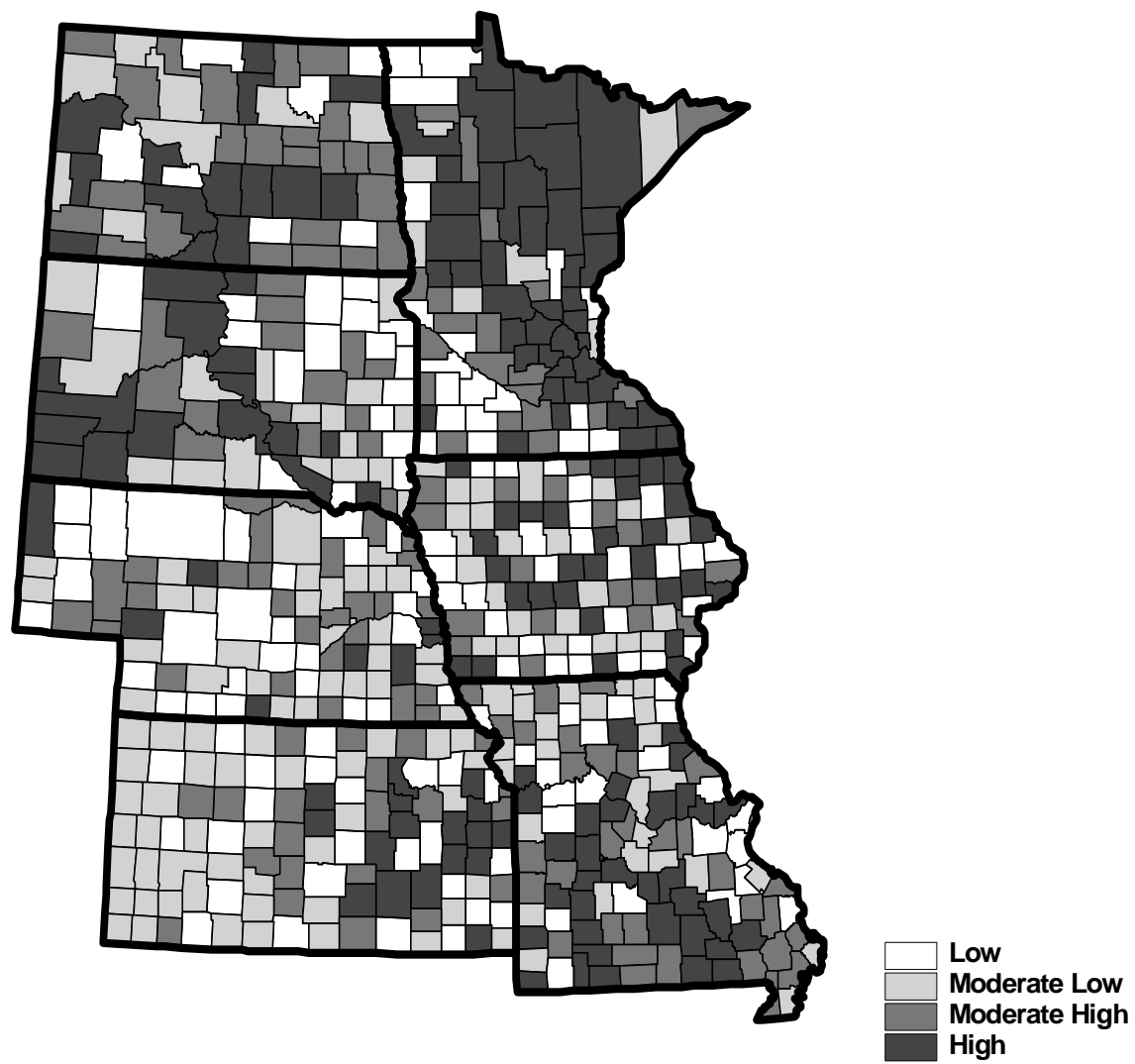

FIGURE 1. Aggregate Indicator of Recreational Amenities - Rankings 
Most counties in our midwest sample can be reasonably described as having a "square" or "rectangular" geometric shape and form a regular lattice. The neighboring recreational amenities are thus assumed to be drawn from the eight nearest counties. ${ }^{4}, 5$ This alternative specification of recreational amenity flows coming from the neighboring counties is represented by

$$
\ln \left(\frac{S_{t+1, i}}{S_{t, i}}\right)=\hat{q}\left(\operatorname{nam}_{i}, \sum_{j \in J_{i}} r_{1, j}, \sum_{j \in J_{i}} r_{2, j}, \sum_{j \in J_{i}} r_{3, j}, \ldots, \sum_{j \in J_{i}} r_{R, j}\right) .
$$

Note in the above equation that recreational amenities have been lagged but natural amenities have not. The recreational amenities chosen here relate to outdoor activities and would generally require some travel to enjoy. However, the natural amenity scale refers to local climatic and topographic amenities and do not require travel to enjoy. As with the previous specification in equation (6), we assume that $\hat{q}($.$) is positive and generally assumed to be$ increasing in its arguments. Note that by including neighboring amenities, it is possible that those production disamenities described earlier may no longer be an issue since the spatial closeness that potentially brings amenities and production into conflict is reduced.

To estimate an economic growth model, we need to postulate functional relationships that incorporate other factors such as knowledge and wage growth identified in equation (5). Considering first growth in $A_{\mathrm{i}}$, we postulate this to be a combination of economic spillovers from surrounding counties, explicit technology produced in the form of patents, and factors related to market access.

$$
\ln \left(\frac{A_{t+1, i}}{A_{t, i}}\right)=g\left(\sum_{j \in N_{i}} \ln \left(\frac{e m p_{t+1, j}}{e m p_{t, j}}\right), \sum_{t, t+1} p a t_{i}, \text { dist }_{i}, I d_{i}\right)
$$

Spatial externalities are believed to play a role in the new geographic economy (Fujita, Krugman, and Venables 1999) and need to be modeled explicitly. This interaction among agents emphasizes the need to jointly consider the behavior of agents rather than independently (Anselin 2003). For county $i$, these spatial growth externalities are assumed to be embodied in employment growth in each of the geographically close counties as defined by the neighborhood structure $N_{i}$. This relationship is hypothesized to generate positive

\footnotetext{
${ }^{4}$ Rather than the queen, which is often associated with this type of contiguity relationship, this type of movement would correspond more correctly to the possible single square movements of the king on a chess board.

${ }^{5}$ Using the latitude and longitude coordinates for each county centroid, eight spatial matrices were created, $W_{1}, W_{2}, w^{3}, \ldots, W_{8}$ so the $n$th row of $W_{d}$ contained a single " 1 " corresponding to the $d$ th nearest county. The neighboring rails-to-trails variable, $r_{1, N}$ for example, would be computed as $r_{1, N_{r}}=\left(W_{1}+W_{2},+W_{3}+\ldots+W_{8}\right) r_{1}$ where $r_{1}$ is an nx1 vector of the rails-to-trails data for each county.
} 
externalities so that higher growth in neighboring counties increases employment growth within the county, i.e., $\frac{\partial g(.)}{\partial \sum_{j \in N_{i}} \ln \left(\frac{e m p_{t+1, j}}{e m p_{t, j}}\right)}>0$. Following numerous other studies, new patents are used as a proxy for new knowledge and innovation (Jaffe 1989; Jaffe, Trajtenberg, and Henderson 1993; Anselin, Varga, and Acs 1997; Hall, Jaffe, and Trajtenberg 2001; Acs, Anselin, and Varga 2002; Peri 2005). Using new county patents summed during the growth period, this measure is expected to contribute positively to knowledge and technology growth, i.e., $\frac{\partial g(.)}{\partial \sum_{t, t+1} p a t_{i}}>0$. The patent database we use was obtained by cross-referencing inventors' addresses obtained from the United States Patent and Trademark Office (USPTO) with a list of cities for each county based on Census county definitions. Using only the first inventor ${ }^{6}$ for each patent, we were able to construct a list of patents by county for the years 1975-2000. The average total number of patents per county for the years 1975-2000 was 125, and the average for the sub-periods 1975-1984 and 19852000 were 37 and 89 patents, respectively (Table 1). Distance to a MSA (dist $t_{i}$ and presence of an interstate within the county $\left(I d_{i}\right)$ are assumed to play a role in the ability of economic agents to interact and act as a proxy for market access. Other things equal we would assume distance to have a negative effect and presence of an interstate to have a positive effect on knowledge growth within the county. The average distance to a MSA was 109 miles, and approximately 28 percent of counties had an interstate (Table 1).

Regional growth effects are taken to be state specific and capture tax rates, state policies governing incentives for new technology and development, and the state growth atmosphere in general. The net state effect can be captured using state dummies $\left(s d_{i}\right)$ associated with county $i$

$$
\ln \left(\frac{R_{t+1, i}}{R_{t, i}}\right)=h\left(s d_{i}\right)
$$

In our sample of midwestern counties, the states of interest are Iowa, Minnesota, Missouri, Kansas, Nebraska, South Dakota, and North Dakota. However, without state-specific information, it is impossible to sign the $h($.$) with respect to any given state.$

The final component of equation (5) that we need to address is wage growth. For this paper we assume wage growth is a function of the initial wage (wage $\left.t_{t, i}\right)$ and initial employment $\left(e m p_{t, i}\right)$ in county $i$

\footnotetext{
${ }^{6}$ First inventor patents were also used by Peri (2005).
} 


$$
\ln \left(\frac{w_{a, t+n, j}}{w_{a, t, i}}\right)=k\left(\text { wage }_{t, i}, e p_{t, i}\right) .
$$

If the wage growth path can be characterized by convergence, initial wages will have a negative effect. In the case of a sticky-wage model, initial employment would have an indeterminate effect on wage growth since both wages and above and below equilibrium will have a positive impact on employment growth as the labor market adjusts. The non-farm employment and wage data used in this analysis comes from Bureau of Economic Analysis (BEA) data compiled on the Regional Economic Information System (REIS) dataset. Wages were computed as total non-farm earnings divided by total non-farm employment. Summary statistics are given in Table 1.

The relationships discussed above can be substituted into the conceptual relationship in equation (5). Assigning logarithmic functions to equations (6) and (8) - (10), we are left with an estimable equation describing employment growth in terms of recreational amenities, new technology, spatial growth spillovers, wages, employment, and other local and regional conditions. $^{7}$

$$
\begin{aligned}
\ln \left(\frac{e m p_{t+1, i}}{e m p_{t, i}}\right)= & \alpha+\beta_{1} \text { nam }_{i}+\sum_{r=1}^{R} \beta_{1, r} r_{r, j}+\rho \sum_{j \in N_{i}} \ln \left(\frac{e m p_{t+1, j}}{e m p_{t, j}}\right)+\lambda_{1} \ln \sum_{t, t+1} \widehat{p a t}_{i} \\
& +\lambda_{2} \ln \text { dist }_{t, i}+\lambda_{3} I d+\sum_{s=1}^{6} \lambda_{s+3} S d_{i}+\lambda_{10} \ln \text { wage }_{t, i}+\lambda_{11} \ln e m p_{t, i}+\varepsilon_{i}
\end{aligned}
$$

where the variables are as described above and $\alpha, \rho$, and the $\lambda$ s and $\beta$ s are parameters to be estimated. Note that in (11) predicted patents, $\widehat{p a t}_{i}$, is used in place of actual patents. Since we are using the sum of patents filed within the county over the same period as employment growth, we may have an endogeneity problem due to growth forces underlying employment growth and new innovations not captured within the model. To overcome this issue we implement a two-stage approach where the fitted values, $\widehat{p a t}_{i}$, are obtained from parameters estimated with the following equation. ${ }^{8}$

\footnotetext{
${ }^{7}$ All equations in this paper are estimated using spatial econometric techniques and take the general form of a spatially lagged dependant variable model: $Y=\rho W Y+X \beta+\varepsilon$ where $Y$ is an nx 1 vector of dependant variables, $W$ is a nxn spatial weights matrix created using a Deluanay Triangulization routine (Pace and LeSage 2004), $X$ is the standard nxk matrix of explanatory variables, $\rho$ is the spatial parameter to be estimated, $\beta$ is a $\mathrm{kx} 1$ vector of parameters to be estimated, and $\varepsilon$ is a disturbance term satisfying the standard classical assumptions.

8 Before taking logarithms, we add one to patents summed.
} 


$$
\begin{aligned}
\ln \sum_{t, t+1} \text { pat }_{i}=\phi_{0} & +\rho_{p a t} \sum_{j \in N_{i}} \ln \sum_{t, t+1} \text { pat }_{i, j}+\phi_{1} \ln \text { pci }_{t, i}+\phi_{2} \ln \text { percol }_{t, i}+\phi_{3} \ln \operatorname{pop}_{t, i} \\
& +\phi_{4} \ln \text { wage }_{t, i}+\phi_{5} I d_{t, i}+\phi_{6} \ln _{e m p} p_{t, i}+\sum_{s=1}^{6} \phi_{s+6} S d_{i}+\varepsilon_{p a t, i}
\end{aligned}
$$

where per capita income ( $p c i$ ), percent of the population over 25 with a college degree (percol), population (pop), and the spatial lag term, $\sum_{j \in N_{i}} \ln \sum_{t, t+1} p_{i} t_{i, j}$ have been introduced as instruments and the others are as defined previously. Income and population data were obtained from the REIS dataset, and percent of the population over the age of 25 with a college degree from Census data. For the growth period 1969-2000, the 1970 Census figures were used; and for the 1985-2000 period, an average of the 1980 and 1990 values were used to estimate the 1985 concentration of college educated individuals within the county.

An alternative specification ascribes employment growth to those recreational amenities in surrounding counties rather than recreational amenities within the county. The neighboring amenity counterpart to equation (11) combines relationships (7), as opposed to (6), and (8)-(10) to obtain

$$
\begin{aligned}
\ln \left(\frac{e m p_{t+1, i}}{e m p_{t, i}}\right)=\alpha & +\beta_{1} \text { nam }_{i}+\sum_{r=1}^{R} \beta_{2, r} \sum_{j \in J_{i}} r_{r, j}+\rho \sum_{j \in N_{i}} \ln \left(\frac{e m p_{t+1, j}}{e m p_{t, j}}\right)+\lambda_{1} \ln \sum_{t, t+1} \widehat{p a t}_{i} \\
& +\lambda_{2} \ln \operatorname{dist}_{t, i}+\lambda_{3} I d+\sum_{s=1}^{6} \lambda_{s+3} S d_{i}+\lambda_{10} \ln \text { wage }_{t, i}+\lambda_{11} \ln e m p_{t, i}+\varepsilon_{i} .
\end{aligned}
$$

Further, we can postulate a model where employment growth is a function of recreational amenities both within and from surrounding counties as represented by

$$
\begin{aligned}
\ln \left(\frac{e m p_{t+1, i}}{e m p_{t, i}}\right)=\alpha & +\beta_{1} \text { nam }_{i}+\sum_{r=1}^{R} \beta_{1, r} r_{r, j}+\sum_{r=1}^{R} \beta_{2, r} \sum_{j \in J_{i}} r_{r, j}+\rho \sum_{j \in N_{i}} \ln \left(\frac{e m p_{t+1, j}}{e m p_{t, j}}\right) \\
& +\lambda_{1} \ln \sum_{t, t+1} \widehat{p a t}_{i}+\lambda_{2} \ln \text { dist }_{t, i}+\lambda_{3} I d+\sum_{s=1}^{6} \lambda_{s+3} S d_{i} \\
& +\lambda_{10} \ln \text { wage }_{t, i}+\lambda_{11} \ln e m p_{t, i}+\varepsilon_{i}
\end{aligned}
$$

The three equations (11), (13), and (14) are the basis for the empirical results discussed in the next section.

\section{RESULTS}

In this section estimation results for employment growth relationships covering the period 1969-2000 and the sub-growth periods 1969-1984 and 1985-2000 are given. The 
models described in the previous section were estimated with the use of spatial econometric techniques. The method of maximum likelihood was used to obtain parameter estimates since ordinary least squares for equations with a spatially lagged dependant variable will result in biased and inconsistent estimates (Anselin 2001). To derive estimates involving a spatially lagged dependent variable, also called a spatial auto-regressive (SAR) model, we follow the algorithm outlined by Anselin (1988). In each SAR model, we further test for spatial autocorrelation using a Lagrange Multiplier test.

To facilitate the discussion, we adopt a notational change and refer to equations (11), (13), and (14) as models (I), (II), and (III), respectively. For each period of study we group the results according to how amenities are captured: first as individual indicators (Table 2) and second using the aggregate amenity indicator displayed in Figure 1 (Tables 3-5). The first set of results looks at all our indicators of recreational amenities. In Table 2 we present the estimation results for each time period with a complete set of technology, spatial, and other control variables plus: (I) own county recreational amenities, (II) neighboring recreational amenities, and (III) both own and neighboring county recreational amenities for the period 1969-2000, and (III) for the years 1969-84 and 1985-2000. Next, using the aggregate indicator of recreational amenities, we repeat models (I), (II), and (III) for each time period and document these results in Tables 5-7. All model estimates presented are based on a spatial model where predicted patents are used rather than actual patents.

The first three columns in Table 2 represents the estimated model coefficients when we consider the entire growth period from 1969-2000. In model (I) in Table 2, the adjusted Rsquare suggests 38 percent of the variation in employment growth over the period is captured. The Lagrange Multiplier for the spatial auto regressive model (LM SAR) is computed to be 0.05 , suggesting a spatial relationship does not exist within the residuals of this model. ${ }^{9}$ In this specification, we find the presence of campgrounds in the home county has a positive and significant impact on employment growth over the study period. In fact, the associated coefficient for the private campground indicator was significantly different from zero at a 99 percent level of statistical confidence. Also found to be positive and significantly different from zero was the coefficient estimate for State Park at the 90 percent level. Interestingly, none of the other recreational amenities were found to be significant in the home county. In the set of results from model (II) in Table 2, some recreational amenities in surrounding counties have a significant role in employment growth. Model (II) for the growth period 1969-2000 was able to explain about 38 percent of the variability in employment growth, and the LM SAR test statistic of 4.47 suggests that we can not rule out a spatial relationship persisting in the model residuals. In this set of results we find that railsto-trails, NRI water-based recreational amenities, and the National Park Service amenities in neighboring counties all have a positive and significant impact on employment growth. Rails-to-trails miles and NRI water acres were all significantly different from zero at a 99

9 The LM SAR test statistic is distributed $\chi^{2}$ with one degree of freedom. The critical value at the 99,95 , and 90 percent levels are $6.63,3.84$, and 2.71 , respectively. 
percent level of confidence; and the NPS variable, created using factor analysis, was significantly different from zero at the 95 percent level. These results indicate that it was not necessarily the recreational amenities in the home county that had a positive impact on employment growth, but rather amenities present in the neighboring counties. In this specification, we also find that the amenity scale parameter is positive and moderately significantly different from zero. The amenity scale, while not explicitly capturing recreational amenities per se, indicates scenic and climatic amenities have a positive impact on employment growth over this period. Interestingly, the variable for State Park amenities actually had a negative (and statistically significant) impact on employment growth over the 1969-2000 period.

The third specification in Table 2, model (III), considers both recreational amenities in the home county as well as recreational amenities in surrounding counties. This model has an adjusted r-square of 0.40 , indicating that 40 percent of the variation in employment growth has been explained by the model. Again, we cannot reject the existence of a spatial relationship in the model residuals based on the LM SAR statistic used to test for residual spatial autocorrelation. In this model specification, we are able to consider the effects of recreational amenities in the home and neighboring counties jointly. Based on the estimated t-statistics for the home and neighboring counties' (Lag) amenities, correlation among these variables does not appear to be a problem. ${ }^{10}$ What is evident is that the general findings from the first two models, (I) and (II), persist in (III). These results taken together indicate that State Parks and private campgrounds are important in the home county, while rails-to-trails, NRI recreational water acres, and NPS recreational amenities are important in neighboring counties. Since we have found some evidence here that certain recreational amenities are important in neighboring counties, rather than within the home county itself, it would be interesting to examine whether this relationship also holds for early and later sub-periods within our sample. However, before doing so we discuss a few notable results from the other explanatory variables.

The spatial interaction and patent parameter estimates both have a positive and significant impact on employment growth. With model (III) estimates for the years 19692000 in Table 2 as the reference, we find that spatial employment spillovers do exist with an estimated value of 0.17 , which is interpreted to mean an increase in the employment growth of surrounding counties by 10 percent will result in a 1.7 percent increase in employment growth in the home county. Note that this spatial interaction represents only a partial effect in the current model; to compute the total spatial spillover effect, one would need to also consider the growth impact that amenities have on neighboring regions, which in turn will affect the growth in the region generating spillovers. The patent parameter can be interpreted to mean that a 10 percent increase in the number of patents filed within the county over the study period will result in 2.5 percent increase in the employment growth within the

${ }^{10}$ If multicolinearity was truly a problem here, we should expect the t-statistics in parentheses to differ greatly between (I) and (III) and between (II) and (III). Since this does not appear to be occurring, we infer this to mean multicolinearity is most likely not an important issue here. 
TABLE 2

Non-Farm Employment Growth - Separate Recreational Amenities

\begin{tabular}{|c|c|c|c|c|c|}
\hline \multirow[t]{2}{*}{ Empl. Growth Period: } & \multicolumn{3}{|c|}{$1969-2000$} & 1969-1984 & $1985-2000$ \\
\hline & \multicolumn{5}{|c|}{ Model Specification } \\
\hline Variable & (I) ${ }^{(a)}$ & (II) & (III) & (III) & (III) \\
\hline \multicolumn{6}{|l|}{$\frac{\underline{\text { Local Climatic and }}}{\text { Scenic Amenities }}$} \\
\hline Amenity Scale & $\begin{array}{c}0.014 \\
(1.234)\end{array}$ & $\begin{array}{l}0.023 \\
(2.144)^{* *}\end{array}$ & $\begin{array}{c}0.008 \\
(0.675)\end{array}$ & $\begin{array}{l}0.013 \\
(1.814)^{*}\end{array}$ & $\begin{array}{l}-0.003 \\
(-0.396)\end{array}$ \\
\hline \multicolumn{6}{|l|}{ Recreational Amenities } \\
\hline $\begin{array}{l}\text { NRI Recreational Land } \\
\text { Acres }\end{array}$ & $\begin{array}{c}0.005 \\
(1.390)\end{array}$ & & $\begin{array}{c}0.005 \\
(1.429)\end{array}$ & $\begin{array}{l}0.004 \\
(2.017)^{* *}\end{array}$ & $\begin{array}{l}-0.000 \\
(-0.135)\end{array}$ \\
\hline Rails to Trails & $\begin{array}{c}0.007 \\
(0.800)\end{array}$ & & $\begin{array}{c}-0.002 \\
(-0.194)\end{array}$ & $\begin{array}{l}-0.001 \\
(-0.108)\end{array}$ & $\begin{array}{l}-0.005 \\
(-0.869)\end{array}$ \\
\hline $\begin{array}{l}\text { NRI Recreational Water } \\
\text { Acres }\end{array}$ & $\begin{array}{c}0.003 \\
(0.642)\end{array}$ & & $\begin{array}{c}0.000 \\
(-0.009)\end{array}$ & $\begin{array}{c}0.000 \\
(-0.003)\end{array}$ & $\begin{array}{l}-0.001 \\
(-0.371)\end{array}$ \\
\hline State Park & $\begin{array}{c}0.010 \\
(1.819)^{*}\end{array}$ & & $\begin{array}{c}0.009 \\
(1.740)^{*}\end{array}$ & $\begin{array}{c}0.005 \\
(1.314)\end{array}$ & $\begin{array}{c}0.003 \\
(1.121)\end{array}$ \\
\hline NPS & $\begin{array}{l}-0.002 \\
(-0.272)\end{array}$ & & $\begin{array}{l}-0.006 \\
(-0.734)\end{array}$ & $\begin{array}{c}0.008 \\
(1.591)\end{array}$ & $\begin{array}{l}-0.012 \\
(-2.662)^{* * *}\end{array}$ \\
\hline Private Campgrounds & $\begin{array}{l}0.063 \\
(4.333)^{* * *}\end{array}$ & & $\begin{array}{l}0.059 \\
(3.984)^{* * *}\end{array}$ & $\begin{array}{l}0.036 \\
(3.725)^{* * *}\end{array}$ & $\begin{array}{l}0.022 \\
(2.586)^{* *}\end{array}$ \\
\hline USDA Forest Service & $\begin{array}{l}-0.004 \\
(-0.716)\end{array}$ & & $\begin{array}{l}-0.005 \\
(-0.787)\end{array}$ & $\begin{array}{l}-0.003 \\
(-0.624)\end{array}$ & $\begin{array}{c}-0.003 \\
(-0.843)\end{array}$ \\
\hline US Army COE & $\begin{array}{c}0.007 \\
(1.572)\end{array}$ & & $\begin{array}{c}0.007 \\
(1.557)\end{array}$ & $\begin{array}{c}0.003 \\
(0.985)\end{array}$ & $\begin{array}{c}0.002 \\
(0.701)\end{array}$ \\
\hline $\begin{array}{l}\text { Lag - NRI Recreational } \\
\text { Land Acres }\end{array}$ & & $\begin{array}{c}-0.003 \\
(-0.518)\end{array}$ & $\begin{array}{c}-0.004 \\
(-0.728)\end{array}$ & $\begin{array}{l}-0.006 \\
(-1.791)^{*}\end{array}$ & $\begin{array}{c}0.001 \\
(0.479)\end{array}$ \\
\hline Lag - Rails to Trails & & $\begin{array}{l}0.020 \\
(2.494)^{* *}\end{array}$ & $\begin{array}{l}0.016 \\
(2.022)^{* *}\end{array}$ & $\begin{array}{c}0.007 \\
(1.308)\end{array}$ & $\begin{array}{l}0.010 \\
(2.218)^{* *}\end{array}$ \\
\hline $\begin{array}{l}\text { Lag - NRI Recreational } \\
\text { Water Acres }\end{array}$ & & $\begin{array}{l}0.046 \\
(3.318)^{* * *}\end{array}$ & $\begin{array}{l}0.043 \\
(3.056)^{* * *}\end{array}$ & $\begin{array}{l}0.020 \\
(2.177)^{* *}\end{array}$ & $\begin{array}{l}0.021 \\
(2.664)^{* * *}\end{array}$ \\
\hline Lag - State Park & & $\begin{array}{l}-0.007 \\
(-3.599)^{* * *}\end{array}$ & $\begin{array}{l}-0.006 \\
(-2.792)^{* * *}\end{array}$ & $\begin{array}{l}-0.002 \\
(-1.797)^{*}\end{array}$ & $\begin{array}{l}-0.003 \\
(-2.184)^{* *}\end{array}$ \\
\hline Lag - NPS & & $\begin{array}{l}0.004 \\
(2.236)^{* *}\end{array}$ & $\begin{array}{l}0.005 \\
(2.573)^{* *}\end{array}$ & $\begin{array}{c}0.002 \\
(1.620)\end{array}$ & $\begin{array}{l}0.003 \\
(2.409)^{* *}\end{array}$ \\
\hline $\begin{array}{l}\text { Lag - Private } \\
\text { Campgrounds }\end{array}$ & & $\begin{array}{c}0.008 \\
(1.585)\end{array}$ & $\begin{array}{c}0.008 \\
(1.523)\end{array}$ & $\begin{array}{c}0.004 \\
(1.126)\end{array}$ & $\begin{array}{c}0.002 \\
(0.696)\end{array}$ \\
\hline $\begin{array}{l}\text { Lag - USDA Forest } \\
\text { Service }\end{array}$ & & $\begin{array}{c}-0.001 \\
(-0.336)\end{array}$ & $\begin{array}{c}-0.001 \\
(-0.641)\end{array}$ & $\begin{array}{l}-0.003 \\
(-1.864)^{*}\end{array}$ & $\begin{array}{c}0.001 \\
(1.134)\end{array}$ \\
\hline Lag - US Army COE & & $\begin{array}{c}0.001 \\
(0.833)\end{array}$ & $\begin{array}{c}0.002 \\
(1.060)\end{array}$ & $\begin{array}{c}0.001 \\
(0.803)\end{array}$ & $\begin{array}{c}0.001 \\
(1.217)\end{array}$ \\
\hline
\end{tabular}




\begin{tabular}{|c|c|c|c|c|c|}
\hline \multirow[t]{2}{*}{ Empl. Growth Period: } & \multicolumn{3}{|c|}{$1969-2000$} & 1969-1984 & $1985-2000$ \\
\hline & \multicolumn{5}{|c|}{ Model Specification } \\
\hline Variable & (I) ${ }^{(\mathrm{a})}$ & (II) & (III) & (III) & (III) \\
\hline \multicolumn{6}{|l|}{$\frac{\text { Technology and }}{\text { Interaction }}$} \\
\hline Spatial Interaction $(\rho)$ & $\begin{array}{l}0.276 \\
(4.891)^{* * *}\end{array}$ & $\begin{array}{l}0.187 \\
(3.180)^{* * *}\end{array}$ & $\begin{array}{l}0.171 \\
(2.867)^{* * *}\end{array}$ & $\begin{array}{l}0.144 \\
(2.340)^{* *}\end{array}$ & $\begin{array}{l}0.240 \\
(4.102)^{* * *}\end{array}$ \\
\hline $\begin{array}{l}\text { (log) Predicted Total } \\
\text { Patents } 1975-2000\end{array}$ & ${ }^{0.201}{ }^{(6.291)^{* * *}}$ & $\begin{array}{l}0.256 \\
(5.606)^{* * *}\end{array}$ & $\begin{array}{l}0.255 \\
(5.663)^{* * *}\end{array}$ & & \\
\hline $\begin{array}{l}\text { (log) Predicted Total } \\
\text { Patents } \quad 1975-1984\end{array}$ & & & & $\begin{array}{l}0.140 \\
(4.566)^{* * * *}\end{array}$ & \\
\hline $\begin{array}{l}\text { (log) Predicted Total } \\
\text { Patents } 1985-2000\end{array}$ & & & & & $\begin{array}{l}0.094 \\
(4.255)^{* * *}\end{array}$ \\
\hline \multicolumn{6}{|l|}{ County Characteristics } \\
\hline $\begin{array}{l}\text { (log) Initial Non-Farm } \\
\text { Wage }\end{array}$ & $\begin{array}{l}-0.282 \\
(1.734)^{*}\end{array}$ & $\begin{array}{c}0.127 \\
(1.094)\end{array}$ & $\begin{array}{c}0.189 \\
(1.641)\end{array}$ & $\begin{array}{c}0.134 \\
(1.666)^{*}\end{array}$ & $\begin{array}{c}0.060 \\
(1.063)\end{array}$ \\
\hline $\begin{array}{l}\text { (log) Initial Non-Farm } \\
\text { Employment }\end{array}$ & $\begin{array}{c}0.017 \\
(-6.876)^{* * *}\end{array}$ & $\begin{array}{l}-0.240 \\
(-5.609)^{* * *}\end{array}$ & $\begin{array}{l}-0.258 \\
(-6.158)^{* * *}\end{array}$ & $\begin{array}{l}-0.128 \\
(-5.401)^{* * *}\end{array}$ & $\begin{array}{l}-0.078 \\
(-3.539)^{* * *}\end{array}$ \\
\hline$(\log )$ Distance to a MSA & $\begin{array}{c}0.015 \\
(0.847)\end{array}$ & $\begin{array}{c}0.018 \\
(0.863)\end{array}$ & $\begin{array}{c}0.023 \\
(1.114)\end{array}$ & $\begin{array}{c}0.022 \\
(1.578)\end{array}$ & $\begin{array}{c}0.006 \\
(0.506)\end{array}$ \\
\hline Presence of Interstate & $\begin{array}{c}0.046 \\
(0.523)\end{array}$ & $\begin{array}{c}0.059 \\
(1.990)^{*}\end{array}$ & $\begin{array}{c}0.036 \\
(1.235)\end{array}$ & $\begin{array}{c}0.029 \\
(1.468)\end{array}$ & $\begin{array}{c}0.006 \\
(0.349)\end{array}$ \\
\hline \multicolumn{6}{|l|}{$\underline{\text { State Effects }}$} \\
\hline Kansas & $\begin{array}{c}0.053 \\
(0.996)\end{array}$ & $\begin{array}{c}0.061 \\
(1.143)\end{array}$ & $\begin{array}{c}0.068 \\
(1.293)\end{array}$ & $\begin{array}{c}0.068 \\
(1.901)^{*}\end{array}$ & $\begin{array}{l}-0.015 \\
(-0.496)\end{array}$ \\
\hline Minnesota & $\begin{array}{c}0.242 \\
(1.000)\end{array}$ & $\begin{array}{c}-0.034 \\
(-0.541)\end{array}$ & $\begin{array}{l}-0.054 \\
(-0.867)\end{array}$ & $\begin{array}{c}0.035 \\
(0.867)\end{array}$ & $\begin{array}{l}-0.040 \\
(-1.159)\end{array}$ \\
\hline Missouri & $\begin{array}{l}0.051 \\
(4.695)^{* * *}\end{array}$ & $\begin{array}{c}0.176 \\
(3.217)^{* * *}\end{array}$ & $\begin{array}{c}0.209 \\
(3.723)\end{array}$ & $\begin{array}{l}0.119 \\
(3.207)^{* * *}\end{array}$ & $\begin{array}{l}0.067 \\
(2.097)^{* *}\end{array}$ \\
\hline Nebraska & $\begin{array}{c}0.049 \\
(1.086)\end{array}$ & $\begin{array}{c}0.046 \\
(0.892)\end{array}$ & $\begin{array}{c}0.046 \\
(0.901)\end{array}$ & $\begin{array}{c}0.041 \\
(1.200)\end{array}$ & $\begin{array}{l}-0.005 \\
(-0.176)\end{array}$ \\
\hline North Dakota & $\begin{array}{c}0.179 \\
(0.845)\end{array}$ & $\begin{array}{c}-0.037 \\
(-0.521)\end{array}$ & $\begin{array}{c}-0.047 \\
(-0.653)\end{array}$ & $\begin{array}{c}0.090 \\
(1.877)^{*}\end{array}$ & $\begin{array}{l}-0.103 \\
(-2.496)^{* *}\end{array}$ \\
\hline South Dakota & $\begin{array}{l}0.271 \\
(3.246)^{* * *}\end{array}$ & $\begin{array}{l}0.131 \\
(2.097)^{* *}\end{array}$ & $\begin{array}{c}0.117 \\
(1.882)^{*}\end{array}$ & $\begin{array}{c}-0.022 \\
(-0.537)\end{array}$ & $\begin{array}{c}0.089 \\
(2.530)^{* *}\end{array}$ \\
\hline Constant & $\begin{array}{c}1.360 \\
(4.635)^{* * *}\end{array}$ & $\begin{array}{l}0.793 \\
(2.389)^{* *}\end{array}$ & $\begin{array}{l}0.848 \\
(2.603)^{* * *}\end{array}$ & $\begin{array}{c}0.435 \\
(1.999)^{* *}\end{array}$ & $\begin{array}{c}0.168 \\
(0.874)\end{array}$ \\
\hline$\underline{\text { Diagnostics }}$ & & & & & \\
\hline R-Square & 0.404 & 0.404 & 0.430 & 0.336 & 0.384 \\
\hline Adjusted R-Square & 0.384 & 0.384 & 0.403 & 0.305 & 0.355 \\
\hline LM SAR & 0.053 & $4.473^{* *}$ & $3.141^{* *}$ & $8.470^{* * *}$ & 0.428 \\
\hline
\end{tabular}


county. Both of these coefficient estimates are significantly different from zero at the 99 percent level. Initial employment is found to have a negative impact on employment growth, with elasticity of -0.26 , and is significantly different from zero with at least a 99 percent level of confidence. Initial wage ${ }^{11}$ is found here to have a positive effect; but at the 90 percent level, it is marginally significant. Interestingly, neither of distance nor presence of an interstate had a significant impact on employment growth in this period. In state-regional effects, only Missouri and South Dakota performed better relative to Iowa. In the remaining model (III) specifications for the years 1969-84 and 1985-2000, similar results hold regarding the patent, spatial spillover, distance, and other initial condition variables.

Returning to our discussion of amenities, the earlier sub-period employment growth from 1969-1984, model (III), estimation results are presented in the fourth column of Table 2. This model is able to explain about 30 percent of the variation in employment growth over this period, about 10 percent less than the comparable model in for 1969-2000. Further, the LM SAR statistic was computed at 8.47 , suggesting a high probability of a spatial relationship in the model residuals. Examining the estimated coefficients for the 1969-84 model specification (III), we find NRI recreational acres and private campgrounds within the county have a positive impact on employment growth. However, only NRI recreational water acres in surrounding counties are found to have a significant positive impact on employment growth. Over this period we actually find that a number of the recreational amenities in surrounding counties had a negative impact on employment growth. The lagged amenities had a significant but negative impact on employment growth, including NRI recreational land, State Park amenities, and USDA forest service amenities. In model (III) we do, however, find that the amenity scale variable had a positive impact at the 90 percent level significance level on employment growth.

The results from the last half of our sample period from 1985-2000 are presented in the last column of Table 2, where we find model specification (III) explains 36 percent of the variation in employment growth. Unlike the previous two model (III) results discussed, we find no evidence for the presence of a spatial relationship in the model residuals. The computed LM SAR test statistic of 0.4 does not allow rejection of the hypothesis of no spatial autocorrelation in model residuals. In this model we once again find that private campgrounds have a positive and statistically significant impact on employment growth. However, this is the only recreational amenity variable within the county itself found to have a positive and significant impact on employment growth. When we examine the recreational amenities in surrounding counties, we find that the rails-to-trails, NRI acres of recreational water, and NPS recreational amenities had a positive and significant impact on employment growth. The evidence for the 1985-2000 period would thus imply that recreational amenities in surrounding counties may have had a more beneficial impact on employment than the amenities within the home county. Given the very land-intensive nature of many of the

${ }^{11}$ Additional sensitivity that included median housing values from the 1970 census as an independent variable for the period 1969-2000 did not appreciably alter our results concerning the amenity variables. 
variables chosen here, this result is not surprising, especially for the 1985-2000 period when an extensive transportation system linked many of the listed recreational amenities to urban centers.

An interesting observation found in each of the three model (III) specifications is the estimated coefficient for State Park recreational amenities in neighboring counties. We find this variable to be negative and statistically significant. This outcome may imply that State Park benefits accrue mainly to residents within the home county while residents in other counties are somehow precluded. In such a situation, it would be the State Park recreational amenities within the county that are important. There is some support for this over the broad growth period, but we did not find statistical evidence in support of this theory for either of the early or later sub-periods examined.

In an effort to shed light on the relative importance of amenities within home versus amenities in surrounding counties, we created an aggregate indicator by combining all recreational amenity variables used in the previous regression analyses into a single amenity indicator using factor analysis in the manner described earlier. We regressed employment growth on this aggregate amenity variable for the home county as well as summed for neighboring counties. These results are given in Tables 3, 4, and 5 for the growth periods 1969-2000, 1969-1984, and 1985-2000, respectively. While estimation results are given for all three models, the specification of interest is (III) where home and neighboring aggregate amenity variables are both included in the model. In Table 3 we find that evidence amenities both within and in neighboring counties contributed significantly to employment growth over the period. When we further examined the role of amenities in each of the sub-periods, we found that whether home or neighboring recreational amenities are important depends on the study period of interest. In Table 4 for the 1969-84 period, we do not find evidence that recreational amenities in the county or in surrounding counties had a significant impact on county employment growth though natural and climatic amenities did. In contrast, for the latter period 1985-2000, we found that the aggregate level of recreational amenities in neighboring counties, but not in the home county, had favorable growth effects (Table 5). Further, the amenity scale is insignificant in this period. The results of Tables 3-5 are generally consistent with the broad observations from Table 2. For the earlier sub-period 1969-1984 recreational amenities do not appear to have had an appreciable impact on county-level employment growth. However, when we examined the latter growth period from 1985-2000, we found recreational amenities from neighboring counties played a positive role in home county employment growth. When using the same measure, amenities in the home county did not have a significant impact.

To test whether our results were robust to controlling for the "ruralness" of a county, we conducted sensitivity analysis by including the rural-urban continuum codes from the ERS of 
TABLE 3

Non-Farm Employment Growth 1969-2000 - Recreation Index

\begin{tabular}{|c|c|c|c|}
\hline \multirow[b]{2}{*}{ Variable } & \multicolumn{3}{|c|}{ Model Specification } \\
\hline & $(\mathrm{I})^{(\mathrm{a})}$ & (II) & (III) \\
\hline \multicolumn{4}{|l|}{ Local Climatic and Scenic Amenities } \\
\hline Amenity Scale & $\begin{array}{l}0.0303 \\
(2.9411)^{* * *}\end{array}$ & $\begin{array}{l}0.0303 \\
(2.9523)^{* * *}\end{array}$ & $\begin{array}{l}0.0278 \\
(2.6829)^{* * *}\end{array}$ \\
\hline \multicolumn{4}{|l|}{ Recreational Amenities } \\
\hline$\overline{\text { Total Recreation Amenity Indicator }}$ & $\begin{array}{l}0.0052 \\
(2.1865)^{* *}\end{array}$ & & $\begin{array}{c}0.0042 \\
(1.7631)^{*}\end{array}$ \\
\hline Lag - Total Recreation Indicator & & $\begin{array}{l}0.0018 \\
(2.6193)^{* * *}\end{array}$ & $\begin{array}{l}0.0016 \\
(2.2649)^{* *}\end{array}$ \\
\hline \multicolumn{4}{|l|}{ Technology and Interaction } \\
\hline Spatial Interaction $(\rho)$ & $\begin{array}{l}0.2908 \\
(5.2373)^{* * *}\end{array}$ & $\begin{array}{c}0.2681 \\
(4.7396)^{* * *}\end{array}$ & $\begin{array}{l}0.2656 \\
(4.6767)^{* * *}\end{array}$ \\
\hline (log) Predicted Total Patents - Summed 1975-2000 & $\begin{array}{c}0.2773 \\
(6.2839)^{* * *}\end{array}$ & $\begin{array}{l}0.2728 \\
(6.1963)^{* * *}\end{array}$ & $\begin{array}{c}0.2764 \\
(6.2901)^{* * *}\end{array}$ \\
\hline \multicolumn{4}{|l|}{ County Characteristics } \\
\hline (log) Non-Farm Wage in 1969 & $\begin{array}{c}0.1430 \\
(1.2366)\end{array}$ & $\begin{array}{c}0.1200 \\
(1.0368)\end{array}$ & $\begin{array}{c}0.1234 \\
(1.0684)\end{array}$ \\
\hline (log) Non-Farm Employment in 1969 & $\begin{array}{l}-0.2616 \\
(-6.3038)^{* * *}\end{array}$ & $\begin{array}{l}-0.2521 \\
(-6.0912)^{* * *}\end{array}$ & $\begin{array}{l}-0.2575 \\
(-6.2242)^{* * *}\end{array}$ \\
\hline (log) Distance to a MSA & $\begin{array}{c}0.0139 \\
(0.6738)\end{array}$ & $\begin{array}{c}0.0164 \\
(0.7904)\end{array}$ & $\begin{array}{c}0.0198 \\
(0.9498)\end{array}$ \\
\hline Presence of Interstate & $\begin{array}{c}0.0310 \\
(1.0473)\end{array}$ & $\begin{array}{c}0.0363 \\
(1.2272)\end{array}$ & $\begin{array}{c}0.0336 \\
(1.1385)\end{array}$ \\
\hline \multicolumn{4}{|l|}{ State Effects } \\
\hline Kansas & $\begin{array}{c}0.0152 \\
(0.3419)\end{array}$ & $\begin{array}{c}0.0104 \\
(0.2328)\end{array}$ & $\begin{array}{c}0.0113 \\
(0.2547)\end{array}$ \\
\hline Minnesota & $\begin{array}{c}0.0919 \\
(1.8763)^{*}\end{array}$ & $\begin{array}{c}0.0855 \\
(1.7313)^{*}\end{array}$ & $\begin{array}{c}0.0772 \\
(1.5609)\end{array}$ \\
\hline Missouri & $\begin{array}{l}0.2061 \\
(4.2233)^{* * *}\end{array}$ & $\begin{array}{l}0.2032 \\
(4.1716)^{* * *}\end{array}$ & $\begin{array}{l}0.2077 \\
(4.2664)^{* * *}\end{array}$ \\
\hline Nebraska & $\begin{array}{c}0.0420 \\
(0.9194)\end{array}$ & $\begin{array}{c}0.0498 \\
(1.0845)\end{array}$ & $\begin{array}{c}0.0516 \\
(1.1272)\end{array}$ \\
\hline North Dakota & $\begin{array}{c}0.0623 \\
(1.1857)\end{array}$ & $\begin{array}{c}0.0643 \\
(1.2255)\end{array}$ & $\begin{array}{c}0.0590 \\
(1.1269)\end{array}$ \\
\hline South Dakota & $\begin{array}{c}0.1909 \\
(3.5450)^{* * *}\end{array}$ & $\begin{array}{l}0.1873 \\
(3.4785)^{* * *}\end{array}$ & $\begin{array}{c}0.1874 \\
(3.4893)^{* * *}\end{array}$ \\
\hline Constant & ${ }^{1.3511}{ }^{* .5845)^{* * *}}$ & $\begin{array}{c}1.3224 \\
(4.4811)^{* * *}\end{array}$ & ${ }^{1.3348}(4.5375)^{* * *}$ \\
\hline \multicolumn{4}{|l|}{$\underline{\text { Diagnostics }}$} \\
\hline R-Square & 0.3759 & 0.3764 & 0.3794 \\
\hline Adjusted R-Square & 0.3625 & 0.3630 & 0.3650 \\
\hline LM SAR & 1.1160 & 2.0170 & 2.6650 \\
\hline
\end{tabular}


TABLE 4

Non-Farm Employment Growth 1969-1984 - Recreation Index

\begin{tabular}{|c|c|c|c|}
\hline \multirow[b]{2}{*}{ Variable } & \multicolumn{3}{|c|}{ Model Specification } \\
\hline & $(\mathrm{I})^{(\mathrm{a})}$ & (II) & (III) \\
\hline \multicolumn{4}{|l|}{ Local Climatic and Scenic Amenities } \\
\hline Amenity Scale & $\begin{array}{l}0.0245 \\
(3.5948)^{* * *}\end{array}$ & $\begin{array}{l}0.0250 \\
(3.6802)^{* * *}\end{array}$ & $\begin{array}{l}0.0238 \\
(3.4743)^{* * *}\end{array}$ \\
\hline \multicolumn{4}{|l|}{ Recreational Amenities } \\
\hline Total Recreation Amenity Indicator & $\begin{array}{c}0.0021 \\
(1.3824)\end{array}$ & & $\begin{array}{c}0.0019 \\
(1.1908)\end{array}$ \\
\hline Lag - Total Recreation Indicator & & $\begin{array}{c}0.0005 \\
(1.1801)\end{array}$ & $\begin{array}{c}0.0004 \\
(0.9453)\end{array}$ \\
\hline \multicolumn{4}{|l|}{ Technology and Interaction } \\
\hline Spatial Interaction $(\rho)$ & $\begin{array}{l}0.2248 \\
(3.8434)^{* * *}\end{array}$ & $\begin{array}{l}0.2148 \\
(3.6422)^{* * *}\end{array}$ & $\begin{array}{l}0.2149 \\
(3.6395)^{* * *}\end{array}$ \\
\hline (log) Predicted Total Patents - Summed 1975-1984 & $\begin{array}{l}0.1664 \\
(5.5753)^{* * *}\end{array}$ & $\begin{array}{l}0.1650 \\
(5.5269)^{* * *}\end{array}$ & ${ }^{0.1661}{ }_{(5.5699)^{* * *}}$ \\
\hline \multicolumn{4}{|l|}{ County Characteristics } \\
\hline (log) Non-Farm Wage in 1975 & $\begin{array}{c}0.0825 \\
(1.0330)\end{array}$ & $\begin{array}{c}0.0754 \\
(0.9415)\end{array}$ & $\begin{array}{c}0.0770 \\
(0.9622)\end{array}$ \\
\hline (log) Non-Farm Employment in 1975 & $\begin{array}{l}-0.1342 \\
(-5.7869)^{* * *}\end{array}$ & $\begin{array}{l}-0.1313 \\
(-5.6602)^{* * *}\end{array}$ & $\begin{array}{l}-0.1331 \\
(-5.7342)^{* * *}\end{array}$ \\
\hline (log) Distance to a MSA & $\begin{array}{c}0.0209 \\
(1.5149)\end{array}$ & $\begin{array}{c}0.0213 \\
(1.5310)\end{array}$ & $\begin{array}{c}0.0228 \\
(1.6311)^{*}\end{array}$ \\
\hline Presence of Interstate & $\begin{array}{c}0.0303 \\
(1.5506)\end{array}$ & $\begin{array}{c}0.0321 \\
(1.6461)^{*}\end{array}$ & $\begin{array}{c}0.0310 \\
(1.5883)\end{array}$ \\
\hline \multicolumn{4}{|l|}{ State Effects } \\
\hline Kansas & $\begin{array}{c}0.0361 \\
(1.2282)\end{array}$ & $\begin{array}{c}0.0356 \\
(1.2096)\end{array}$ & $\begin{array}{c}0.0358 \\
(1.2177)\end{array}$ \\
\hline Minnesota & $\begin{array}{l}0.1026 \\
(3.3152)^{* * *}\end{array}$ & $\begin{array}{c}0.1019 \\
(3.2480)^{* * *}\end{array}$ & $\begin{array}{l}0.0983 \\
(3.1246)^{* * *}\end{array}$ \\
\hline Missouri & $\begin{array}{l}0.1145 \\
(3.6092)^{* * *}\end{array}$ & $\begin{array}{l}0.1130 \\
(3.5631)^{* * *}\end{array}$ & ${ }^{0.1146}(3.6146)^{* * *}$ \\
\hline Nebraska & $\begin{array}{c}0.0432 \\
(1.4449)\end{array}$ & $\begin{array}{c}0.0454 \\
(1.5108)\end{array}$ & $\begin{array}{c}0.0461 \\
(1.5351)\end{array}$ \\
\hline North Dakota & $\begin{array}{c}0.1362 \\
(3.8466)^{* * *}\end{array}$ & $\begin{array}{l}0.1386 \\
(3.9144)^{* * *}\end{array}$ & $\begin{array}{c}0.1363 \\
(3.8499)^{* * *}\end{array}$ \\
\hline South Dakota & $\begin{array}{c}0.0161 \\
(0.4779)\end{array}$ & $\begin{array}{c}0.0150 \\
(0.4444)\end{array}$ & $\begin{array}{c}0.0146 \\
(0.4326)\end{array}$ \\
\hline Constant & $\begin{array}{l}0.7096 \\
(3.6205)^{* * *}\end{array}$ & $\begin{array}{l}0.7005 \\
(3.5647)^{* * *}\end{array}$ & $\begin{array}{l}0.7029 \\
(3.5827)^{* * *}\end{array}$ \\
\hline \multicolumn{4}{|l|}{$\underline{\text { Diagnostics }}$} \\
\hline R-Square & 0.2894 & 0.2882 & 0.2898 \\
\hline Adjusted R-Square & 0.2741 & 0.2729 & 0.2733 \\
\hline LM SAR & $4.0630^{* *}$ & $4.2610^{* *}$ & $5.1050^{* *}$ \\
\hline
\end{tabular}


TABLE 5

Non-Farm Employment Growth 1985-2000 - Recreation Index

\begin{tabular}{|c|c|c|c|}
\hline \multirow[b]{2}{*}{ Variable } & \multicolumn{3}{|c|}{ Model Specification } \\
\hline & $(\mathrm{I})^{(\mathrm{a})}$ & (II) & (III) \\
\hline \multicolumn{4}{|l|}{ Local Climatic and Scenic Amenities } \\
\hline Amenity Scale & $\begin{array}{c}0.0077 \\
(1.3600)\end{array}$ & $\begin{array}{c}0.0058 \\
(1.0295)\end{array}$ & $\begin{array}{c}0.0051 \\
(0.9026)\end{array}$ \\
\hline \multicolumn{4}{|l|}{ Recreational Amenities } \\
\hline Total Recreation Amenity Indicator & $\begin{array}{c}0.0017 \\
(1.2774)\end{array}$ & & $\begin{array}{c}0.0010 \\
(0.7667)\end{array}$ \\
\hline Lag - Total Recreation Indicator & & $\begin{array}{c}0.0013 \\
(3.1923)^{* * *}\end{array}$ & $\begin{array}{l}0.0012 \\
(3.0111)^{* * *}\end{array}$ \\
\hline \multicolumn{4}{|l|}{ Technology and Interaction } \\
\hline Spatial Interaction $(\rho)$ & $\begin{array}{l}0.3153 \\
(5.6372)^{* * *}\end{array}$ & $\begin{array}{c}0.2831 \\
(4.9529)^{* * *}\end{array}$ & $\begin{array}{l}0.2826 \\
(4.9335)^{* * *}\end{array}$ \\
\hline (log) Predicted Total Patents - Summed 1985-2000 & $\begin{array}{c}0.1026 \\
(4.8011)^{* * *}\end{array}$ & $\begin{array}{c}0.0985 \\
(4.6314)^{* * *}\end{array}$ & $\begin{array}{c}0.0981 \\
(4.6145)^{* * *}\end{array}$ \\
\hline \multicolumn{4}{|l|}{ County Characteristics } \\
\hline (log) Non-Farm Wage in 1985 & $\begin{array}{c}0.0357 \\
(0.6301)\end{array}$ & $\begin{array}{c}0.0284 \\
(0.5052)\end{array}$ & $\begin{array}{c}0.0308 \\
(0.5471)\end{array}$ \\
\hline (log) Non-Farm Employment in 1985 & $\begin{array}{c}-0.0796 \\
(-3.7004)^{* * *}\end{array}$ & $\begin{array}{l}-0.0736 \\
(-3.4320)^{* * *}\end{array}$ & $\begin{array}{l}-0.0739 \\
(-3.4481)^{* * *}\end{array}$ \\
\hline$(\log )$ Distance to a MSA & $\begin{array}{c}0.0004 \\
(0.0347)\end{array}$ & $\begin{array}{c}0.0034 \\
(0.3103)\end{array}$ & $\begin{array}{c}0.0038 \\
(0.3514)\end{array}$ \\
\hline Presence of Interstate & $\begin{array}{c}-0.0019 \\
(-0.1142)\end{array}$ & $\begin{array}{c}0.0008 \\
(0.0514)\end{array}$ & $\begin{array}{c}0.0004 \\
(0.0261)\end{array}$ \\
\hline \multicolumn{4}{|l|}{$\underline{\text { State Effects }}$} \\
\hline Kansas & $\begin{array}{c}-0.0353 \\
(-1.3683)\end{array}$ & $\begin{array}{c}-0.0416 \\
(-1.6165)\end{array}$ & $\begin{array}{c}-0.0416 \\
(-1.6171)\end{array}$ \\
\hline Minnesota & $\begin{array}{c}0.0361 \\
(1.4019)\end{array}$ & $\begin{array}{c}0.0243 \\
(0.9365)\end{array}$ & $\begin{array}{c}0.0229 \\
(0.8787)\end{array}$ \\
\hline Missouri & $\begin{array}{l}0.0754 \\
(2.7294)^{* * *}\end{array}$ & $\begin{array}{l}0.0729 \\
(2.6527)^{* * *}\end{array}$ & $\begin{array}{l}0.0737 \\
(2.6818)^{* * *}\end{array}$ \\
\hline Nebraska & $\begin{array}{c}-0.0120 \\
(-0.4690)\end{array}$ & $\begin{array}{c}-0.0062 \\
(-0.2450)\end{array}$ & $\begin{array}{c}-0.0060 \\
(-0.2373)\end{array}$ \\
\hline North Dakota & $\begin{array}{c}-0.0499 \\
(-1.6602)^{*}\end{array}$ & $\begin{array}{c}-0.0545 \\
(-1.8228)^{*}\end{array}$ & $\begin{array}{c}-0.0560 \\
(-1.8680)^{*}\end{array}$ \\
\hline South Dakota & $\begin{array}{l}0.1173 \\
(3.9956)^{* * *}\end{array}$ & $\begin{array}{c}0.1167 \\
(3.9940)^{* * *}\end{array}$ & $\begin{array}{c}0.1160 \\
(3.9725)^{* * *}\end{array}$ \\
\hline Constant & $\begin{array}{l}0.4766 \\
(2.7159)^{* * *}\end{array}$ & $\begin{array}{l}0.4494 \\
(2.5686)^{* *}\end{array}$ & $\begin{array}{l}0.4441 \\
(2.5388)^{* *}\end{array}$ \\
\hline \multicolumn{4}{|l|}{ Diagnostics } \\
\hline R-Square & 0.3424 & 0.3490 & 0.3495 \\
\hline Adjusted R-Square & 0.3283 & 0.3349 & 0.3344 \\
\hline LM SAR & 0.1490 & 0.1070 & 0.2460 \\
\hline
\end{tabular}


the USDA. ${ }^{12}$ With a ranking for each county ranging from 1 to 9 , low values indicating more urban and higher values indicating increasingly rural, the 1974 classifications were included in the 1969-2000 and 1968-1984 models, and 1993 codes were included as an independent variable for the 1985-2000 model. These results were generally consistent with those discussed above with a few differences. A few points of departure when including the ERS rural-urban codes were the general lack of significance in the spatially lagged rails to trails and State Park variables, while the spatially lagged private campground variable was found to be positive and significant for the 1969-2000 growth period. It is also interesting to note that when incorporating the rural-urban continuum code the coefficient estimate was negative and highly significant in all specifications, indicating that counties that are more rural grew at a slower rate.

\section{CONCLUSIONS AND EXTENSIONS}

We examine the relationship between non-farm employment growth and recreational amenities, both in the home county and in neighboring counties, while controlling for other correlates of economic growth during the 1969-2000 period for midwest counties. The spatial relationship between employment activity and amenities prompts us to consider how spatial location of amenities affects growth. To compress a large amount of recreational amenity data into a more manageable set of indicators, we combined the data using simple sums where applicable (i.e., miles of trail) and principal component analysis where data were of varying scale and simply summing the data would be inadequate (i.e., fishing sites and cross-county skiing). The use of principal component analysis to create individual amenity measures follows in a manner similar to Deller et al. (2001). While we do find some evidence that recreational amenities can contribute to home county employment growth, our analysis has indicated that aside from a few indicators such as private campgrounds, there is limited evidence that employment growth has reacted much, if at all, to other recreational amenities within the county. This result is consistent with Lewis, Hunt, and Plantinga (2002; 2003), who found that employment growth was not significantly influenced by public conservation lands. What we do find, however, is that during the growth period 1969-2000 and especially the later growth period 1985-2000, recreational amenities in surrounding counties as indicated by rails-to-trails miles, NRI acres available for water recreation, and NPS recreational amenities appear to have had a positive and significant effect on employment growth in the home county. In the context of metropolitan and urban development, this result should not be surprising. Many of the amenities we considered require large open spaces that are, by definition, incompatible with heavy urban development. To find that growth in one county is being fueled partly by amenities in surrounding regions certainly makes sense in terms of urban growth.

Of course, while the growth variable of interest in this paper was non-farm employment, this does not necessarily limit the policy implications to this variable alone. While further

12 These codes are available at http://www.ers.usda.gov/Data/RuralUrbanContinuumCodes/. 
research is needed to draw a complete picture, a number of studies have shown there is a positive relationship between population and employment growth (Greenwood, Hunt, and McDowell 1986; Boarnet 1994; Carlino and Mills 1987; and Clark and Murphy 1996). Thus it is possible that a number of the results derived from this study still apply in a more general economic growth framework incorporating other economic variables such as population and income. Of course, more research is required to examine precisely why recreational amenities in neighboring counties contribute positively to county non-farm employment growth, of which the production disamenity and urban development constraints are possible explanations. However, given the caveat of additional research, our findings raise some interesting questions. Many rural counties have debated regional growth initiatives. If amenity development is a strong contender, which locales will benefit? Is there an increased justification for coordinated, as opposed to competing, development initiatives among neighboring counties? These are questions that will need to be addressed by future research.

\section{REFERENCES}

Acs, Z.J., L. Anselin, and A. Varga, 2002. "Patents and Innovation Counts as Measures of Regional Production of New Knowledge," Research Policy 31(Sept.), 1069-1085.

Anselin, L. 1988. Spatial Econometrics: Methods and Models. Kluwer Academic Publishers: Dordrecht, Boston, and London. , 2001. "Spatial Econometrics," in B. Baltagi (ed.), A Companion to Theoretical Econometrics. Blackwell: Malden, MA and Oxford: 310-330. , 2003. “Spatial Externalities," International Regional Science Review 26(April), 147152.

Anselin, L., A. Varga, and Z. Acs, 1997. "Local Geographic Spillovers between University Research and High Technology Innovations," Journal of Urban Economics 42, 422-448.

Betz, C.J. and H.K. Cordell, 1998. "Outdoor Recreation Supply in the United States: A Description of the Resources, Data, and Other Information Sources," USDA Forest Service, Southern Research Station Athens, Last accessed May 14, 2007 at: www.srs. fs.fed.us/ recreation/norsisreport.pdf

Blomquist, G.C., M.C. Berger, and J.P. Hoehn, 1988. "New Estimates of the Quality of Life in Urban Areas," American Economic Review 78 (Mar.), 89-107.

Boarnet, M., 1994. "The Moncentric Model and Employment Location," Journal of Urban Economics 36(1), 79-97.

Carlino, G.A. and E.S. Mills, 1987. "The Determinants of County Growth," Journal of Regional Studies 27(1), 39-54.

Castle, E.N., 1998. "A Conceptual Framework for the Study of Rural Places," American Journal of Agricultural Economics 80(Aug.), 621-631.

Clark, D.E. and C. Murphy, 1996. "County Wide Employment and Population Growth: Analysis from the 1980's," Journal of Regional Science 36(2), 235-256.

Deller, S.C., T. Tsai, D.W. Marcouiller, and D.B.K English, 2001. "The Role of Amenities and Quality of Life in Rural Economic Growth," American Journal of Agricultural Economics 83(May), 352-365. 
Dissart, J.C., and S.C. Deller, 2000. "Quality of Life the Planning Literature," Journal of Planning Literature 15(Aug.), 135-161.

Fujita, M., P. Krugman, and A. Venables, 1999. The Spatial Economy: Cites, Regions, and International Trade. MIT Press: Cambridge MA.

Glaeser, E.L, H.D. Kallal, J.A. Sheinkman, and A. Shleifer, 1992. "Growth in Cities," Journal of Political Economy 100(6), 1126-1152.

Glaeser, E.L., J.A. Scheinkman, and A. Schleifer, 1995. "Economic Growth in a CrossSection of Cities," Journal of Monetary Economics 36, 117-143.

Gottlieb, P.D., 1995. "Residential Amenities, Firm Location and Economic Development," Urban Studies 32(9), 1412-1436.

Greenwood, M.J., G.L. Hunt, and J.M. McDowell, 1986. "Migration and Employment Change: Empirical Evidence of the Spatial and Temporal Dimensions of the Linkage," Journal of Regional Science 26(2), 223-234.

Hall, B., A. Jaffe, and M. Trajtenberg, 2001. "The NBER Patents Citations Data File: Lessons, Insights and Methodological Tools," National Bureau of Economic Research working paper 8498: Cambridge, MA.

Halstead, J.M. and S.C. Deller, 1997. "Public Infrastructure in Rural Manufacturers," Journal of Community Development Society 28(2), 149-169.

Henderson, J.R. and K. McDaniel, 2005. "Natural Amenities and Rural Employment Growth: A Sector Analysis," The Review of Regional Studies 35(1), 80-96.

Jaffe, A.B., 1989. "Real Effects of Academic Research," The American Economic Review 79(Dec.), 957-970.

Jaffe, A.B., M. Trajtenberg, and R. Henderson, 1993. "Geographic Localization of Knowledge Spillovers as Evidenced by Patents," The Quarterly Journal of Economics 108(Aug.), 577-598.

Khan, R., P.F. Orazem, and D.M. Otto, 2001. "Deriving Empirical Definitions of Spatial Labor Markets: The Roles of Competing versus Complementary Growth," Journal of Regional Science 41(4), 735-756.

Lewis, D.J., G.L. Hunt, and A.J. Plantinga, 2004. "Public Conservation Land and Employment Growth in the Northern Forest Region," Land Economics 78(May), 245259.

, 2003. "Does Public Lands Policy Affect Local Wage Growth?” Growth and Change 34(Winter), 64-86.

Lucas, R.E., 1988. "On the Mechanics of Economic Development," Journal of Monetary Economics 12, 3-42.

Marchante, A.J. and B. Ortega, 2006. "Quality of Life and Economic Convergence Across Spanish Regions, 1980-2001," Regional Studies 40(July), 471-483.

McGranahan, D., 1999. "Natural Amenities Drive Rural Population Change," U.S. Department of Agriculture, Agricultural Economic Report No. 781: Washington, D.C.

Pace, R.K. and J.P. Lesage, 2004. "Chebyshev Approximation of log-Determinants of Spatial Weight Matrices," Computational Statistics and Data Analysis 45,179-196.

Peri, G., 2005. "Determinants of Knowledge Flows and Their Effect on Innovation," The Review of Economics and Statistics 87(May), 308-322.

Roback, J., 1982. "Wages, Rents, and the Quality of Life," The Journal of Political Economy 90(6), 1257-1278. 
, 1988. "Wages, Rents, and Amenities: Differences Among Workers and Regions," Economic Inquiry 26(Jan.), 23-41.

Romer, P., 1986. “Increasing Returns and Long-Run Growth,” Journal of Political Economy 94, 1002-1037.

Royuela, V. and M. Artís, 2006. "Convergence Analysis in Terms of Quality of Life in the Urban Systems of Barcelona Province, 1991-2000," Regional Studies 40(July), 485-492.

Rudzitis, G., 1999. "Amenities Increasingly Draw People to the Rural West," Rural Development Perspectives 14(2), 9-13.

Voith, R., 1991. "Capitalization of Local and Regional Attributes into Wages and Rents: Differences Across Residential, Commercial and Mixed-Use Communities," Journal of Regional Science 31(2), 127-145. 